\title{
Characterization of wheat/Aegilops ventricosa introgression and addition lines with respect to the $M^{v}$ genome
}

\author{
M. Mena. I. Orellana. I. Lopez-Braña. E. Garcia-Olmedo. and A. Delibes \\ Department it Biochemistry and Moliecular Biology. E. T. S. Ingenieros Agronomos-UPM. E-28040 Madrid. Spain
}

Recetred Way 13, 1992: Accepted September 29, 1992

Communicated by J. W. Srape

Summary. Stable wheat-Aegilops introgression lines with ti chromosomes (H-93), derived by repeated setfing from a cross I Tritiatum turgidum $\times$. Aegilips rentricosas $\times T$. aesntwm. have been characterized asing the following DNA probes and isozyme markers: (I) single or low-copy DNA tragments from de. rentricesa: (2) known cD.it probes corresponding to $x \mid$-thionin. monomeric $x$-amylase inhibitor. the C.M 3 subunit of tetrameric $x$-amytase inhibitor. and sucrose synthase from whear: (3) anonymous $\triangle D: V_{A}$ probes from wheat that have been mapped by Sharp et al. $11989 \mathrm{k}:(t)$ isozyme markers corresponding to aconitase. shikimate dehydrogenase, adenylate kinase. and indopeptidase. Meiotic metaphases of appropriate hybrids involving selected H-93 lines have been investigated by the Gicmsa $\mathrm{C}$-banding technique. The substitution of whole chromosomes $\left[(5 \mathrm{~A}) 5 \mathrm{M} \mathrm{M}^{2}: 1+D\right]+\mathrm{M}^{2}$ : 15D) $\left.5 \mathrm{M}^{\mathrm{v}}: 17 \mathrm{D}, 7 \mathrm{M} \mathrm{M}^{7}\right)$ and chromosomal segments $11 \mathrm{M}^{\mathrm{2}}$ : $\left.3 \mathrm{M}^{*}: 5 \mathrm{M}^{*}: 3 \mathrm{M}^{\mathrm{v}}\right)$ from the $\mathrm{M}^{2}$ genome of tegilops tentricos $a$ has been demonstrated. The distribution of selected markers among putative wheat-.te. rentricosa addition lines has also been investigated. The $7 \mathrm{M}^{\mathbf{2}}$ addition has been characterized for the first time. while the identity of the previously reported $5 \mathrm{M}^{2}$ and $6 \mathrm{M}^{2}$ additions has been conjirmed.

Key words: tegilops rentricosa - DNA probes - Introgression lines - Addition lines - Triticum uestivum

\section{Introduction}

The wild grass tegilops ventricosa Tausch.. an alloretraploid $\left(2 n=28\right.$ : genomes $\left.D^{*} D^{v}: M^{v} M^{*}\right)$, has attracted considerable attention as a source of genes for resistance to pathogens such as the fungi Psetudocercosporella herpotrichoides (eyespot disease). Erysiphe graminis sp. tririci ipowdery midewl. and Puccinia recundita brown leaf rust: Sprague 1936: Dosba et al. 1980. 1982: and othersl: to insects. such as . Hayetiola destructor (Jones 1938): and to the cyst nematode Heterodera crenae IDosba and Rivoal 19811 . The $D^{*}$ genome of te. ventricosa is evolistionarily close to the $D$ genome of hexaploid wheat. Triticun uesirum L. (genomes AABBDD). whereas the $\mathrm{M}^{*}$ genome is more distantly related (Dosba 1985 ). Interspecific hybrids between the two species can be obtained only with difficulty IDosba and Cauderon 1972). In these hybrids. chromosomes from the $D^{*}$ and the $D$ genome pair at meiosis and recombination occurs, while those of the $\mathrm{M}^{*}$ genome do not pair or recombine. except under exceptional circumstances (Dosba 1974: Mena 1990).

Genetic material from te. ventricosa has been transferred to hexaploid wheat through an intermediate setrsterile hybrid between T. turgidum (AABB) and Ae. ventri$\cos a\left(\mathrm{D}^{*} \mathrm{D}^{v} \mathrm{M}^{2} \mathrm{M}^{v}\right)$, which was backcrossed using pollen from hexaploid wheat (AABBDD), and the progeny were repeatedly selfed to obtain stable wheat lines with 42 chromosomes. designated $\mathrm{H}-93$ lines (Delibes and Garcia-Olmedo 1973; Delibes et al. 1977a. b: Doussinault et al. (983).

Five potential wheatide. ventricosa addition lines have already been characterized on the basis of cytological. morphological. and agronomic characters (Dosba and Doussinault 1978). Three of these have been further identified as corresponding to lines carrying chromosomes $+M^{*}{ }_{1}$ Delibes et al. 1981: Mena et al. 1989). $5 \mathrm{M}^{2}$ (Delibes et al. 1981: Dosba 1985) and 6 $\mathrm{M}^{\mathrm{v}}$ (Dosba 1985).

We have now further characterized these $\mathrm{H}-93$ lines using DNA probes and biochemical markers. as well as cytological methods. Additionally. a disomic addition line carrying chromosome $7 \mathrm{M}^{2}$ has been identified. 


\section{Materials and methods}

\section{Plont materials}

The $\mathrm{H} .93$ lines usect in this study, all of which had been derived from the cross (Triticum turgidum $\mathrm{H}-1+1 \times$. fegifops rentricosed AP-11×T aeshisum cv "Almatense" H-10-15. have been previously described (Delibes and Garcia-Olmedo 1973: Delibes et al. 1977 bl. Appropriate $\mathrm{H}-93$ lines were hybridized to the $\mathrm{H}-10-15$ parent or to ditelosomic stocks of $\vec{T}$. testivum cv "Chinese Spring". Wheat te. rentricosa addition lines were the gift of $F$. Dosba (Dosba and Doussinault 1978: Dosba 1985), and a (6D) $6 \mathrm{M}^{2}$ substitution line, a gift from $\mathrm{J}$. Jahier.

Comstruction of a $a D N A$ library and selection of gDNA probes

Total DNA from te. rentricosa was extracted from dark-grown secedlings as described by Murray and Thompson (1980) with modifications (Rogers and Bendich 1988). The DNA was digested to completion with the Sau3AI restriction endonuclense, and iragments between $0.5 \mathrm{~kb}$ and $\mathrm{l} \mathrm{kb}$ were selected by preparative clectrophoresis on $0.3^{n \prime}$ agarose gels and cloned into the $B$ am HI site of plasmid pUC18. DNAs from in ordered collection of clones were hubridized with total DNAs from te. rentricosat and $T$. aswirm that had been $\left[^{3 \pm P \mid}\right.$-labelled by the random primer procedure IFeinberg and Vogetstein 1983) under experimental procedures described by Landry and Michetmorc (1985).

-D.V.t probes

Inscrts from IDNA clones corresponding to the following proteins were used in this study: $x 1$-thionin I WTI: probe pTT I). sucrose synthase ISsl: probe P11, monomeric $x$-imylase inhibitor (tA.U. syn. WMA1-1: probe PUP23) from wheat, gift from C. Warano. and wheat tetrameric $x$-amylase inhibitor, (subunit CM3. syn. WTAl-3: probe pCTI, the gift of F. Garcia-Maroto. Ten anonymous $2 D N A$ probes corresponding to previously loeated homocology sets (Sharp et al. 1989) were kindly provided by M. Gale I. Norwich. L'Ki.

\section{lso:lame markiers}

Isozymes of endopeptidase (EP) were extructed from individual smbryos and separated by isoelectric focusing using the technique described by Koebner et al. \{1988\} and modified by Mena (1990). Adenylate kinuse (ADK), aconitase (ACOI and shikimate dehydrogenise (SKDH) isozymes were analyzed using extracts from leaves collected from 13-day-old green plants. The leaves were extracted with water (1:1: w:v), and electrophoresis was performed in horizontal electrostarch gets $(12 \%$ w:v 1 at a constant voltage $150 \mathrm{~V}$ and at a temperature of $2^{c}-4: C$ for $4 \mathrm{~h}$. The gets were stained for adenylate kinase according to Benito et al. (1990), for aconitase according to Chenicek and Hart (1987), and fot shikimate dehydrogenase following Koebner and Shepherd 11982).

\section{RFLP unalysis}

DNiks were extracted as described above and subjected to digestion by restriction endonucleases and electrophoresis in $0.75 \%$ agarose gels. Southern blotting and $\mathrm{LV}$ cross-linking to nylon membranes (Hybond-N. Amersham) were carried out by standard procedures (Sambrook et al. 1989). The probes were [ $\left.{ }^{32} \mathrm{P}\right]$ labetled according to Feinberg and Vogelstein $1198 \mathrm{j}$ ).

\section{Cyological procedtures}

$M$ Mioric analysis was carried out after fixation of the anthers in acetic acid:ethanol $(1: 3)$ at ${ }^{\circ} \mathrm{C}$ for 2 months following the Giemin $C$-banding technique described by Giraldez et al. (1979).
Table 1. Sizes of doned DNA fragments from te. ventricosa used as probes

\begin{tabular}{llll}
\hline Probe & kb & Probe & kb \\
\hline abm! & $\mathbf{0 . 7 7}$ & abm 6 & 0.56 \\
abm2 & $\mathbf{0 . 4 5}$ & abm 7 & 0.35 \\
abm3 & $\mathbf{0 . 8 2}$ & abm 8 & 0.42 \\
abm4 & $\mathbf{0 . 7 5}$ & abm 9 & 0.50 \\
abm5 & 0.46 & abm 10 & 0.65 \\
\hline
\end{tabular}

\section{Results ,}

\section{Selection of markers}

A genomic library of te rentricasa DNA digested with the Sau3Al restriction endonuclease was obtained in piasmid pUC18. An ordered collection of clones from this library were blotted onto filters and sequentially hybridized with radioactively labelled DNA from te. ventricosa and from $T$. aestivum in order to select inserts corresponding to low- and single-copy sequences. The sefected inserts were used as probes to investigate polymorphism among the DNAs of te. ventricosa. T. turgichum. and $T$. asstivum. the parental material used to derive the $H-93$ lines. The DNAs were separately digested with four restriction endonucleases: BamHI. BgIII. $H$ indIII. and $E_{c o}$ RI. Out of the 23 inserts tested 10 gave differential bands for Ae. ventricosa in the Southern blot analysis with at least one of the enzymes. Designations and sizes of the inserts are presented in Table 1 , and the most informative pattern for each of those probes is presented in Fig. 1. Fragments corresponding to the $\mathrm{M}^{2}$ genome of te. tentricosa were assigned on the basis of their low frequency of appearance in the $\mathrm{H}-93$ lines $(<3 \%)$. whereas those corresponding to the $D^{v}$ genome appeared at a high frequency $(18 \%-80 \%)$. In the case of probes abm3 and abm9 (not shown), the differential $\left(M^{2}\right)$ fragment did not appear in any of the $\mathrm{H}-93$ lines. Only in those cases in which $\mathrm{M}^{v}$ fragment(s) substituted for $D$ fragment(s) are the latter indicated.

Fourteen anonymous CDNA probes from $T$ aestivum that had been previously characterized by Southern blot analysis of DNAs from cv "Chinese Spring" and its aneuploids (Sharp er al. 1989) were similarly screened for $A \boldsymbol{e}$. ventricosa differentia! patterns. and only 10 gave informative patterns with the enzymes used. Thus. 30 out of the 42 chromosome arms in hexaploid wheat were covered. Four of the identified cDNAs were also used as probes. In Fig. 2 patterns obtained for the parental species of the $\mathrm{H} .93$ lines are compared with those of wheat $\mathrm{CV}$ "Chinese Spring": criteria for the identification of the $\mathrm{M}^{\mathrm{v}}$ fragments were as in Fig. 1. Only in those cases in which $M^{v}$ fragment(s) substituted for fragment(s) from other genomes are the latter indicated on the basis of previous mapping 


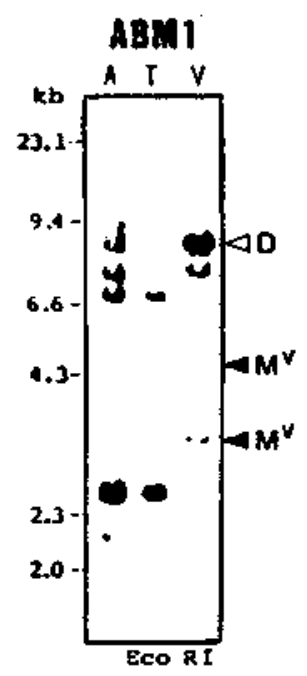

ABM6

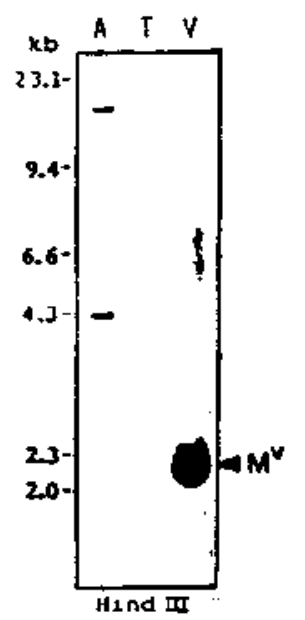

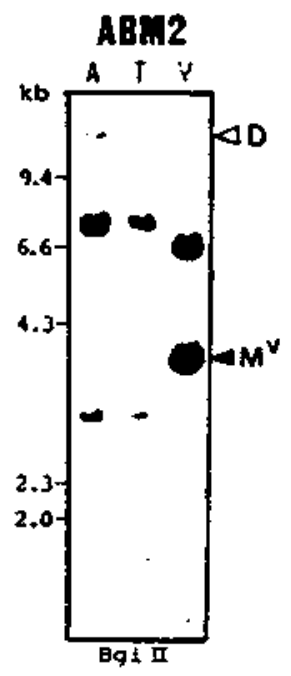

ABM7

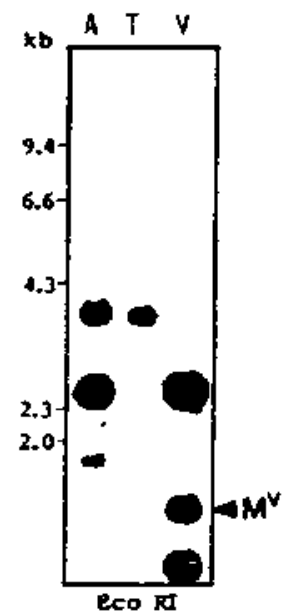

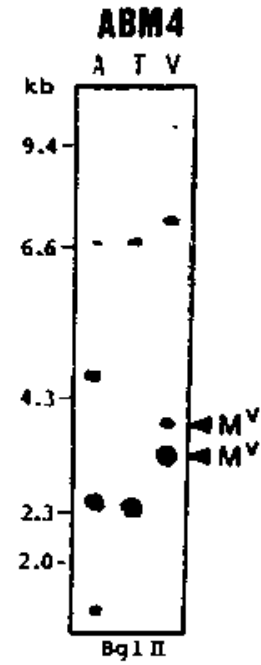

ABM8

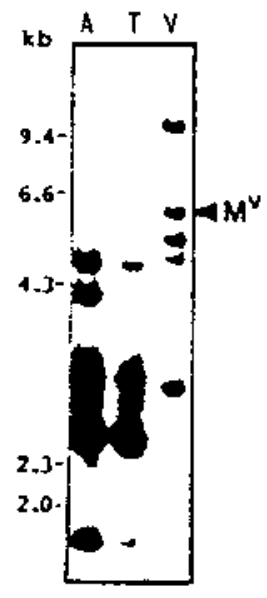

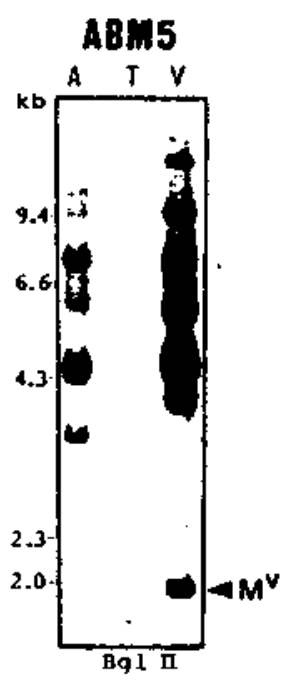

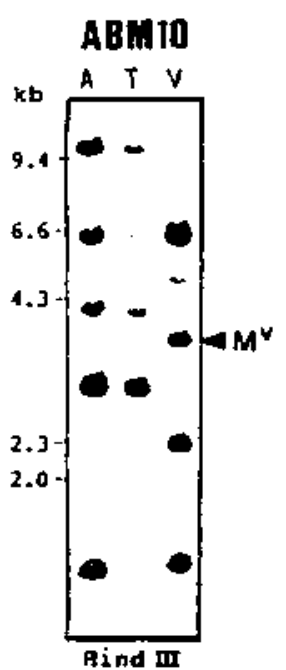

Fig. 1. Southern blot hubridization patterns of DNids from Triticum aeshirem (w "Almalense" $\mathrm{H}-10-15$ (.t). T. turgidtm $\mathrm{H}-1-1$ i $T$. and tegilons rentrictoia AP+1 (b) using cloned segments oi genomic Divit irom te. ventricosu as probes. Diagnostic bands corresponding to the $\mathrm{M}^{v}$ and the $\mathrm{D}$ genomes are indicated with ur. rominous.s in 6 "Chinese Spring" or on the present patterns i.e.. bands present both in the tetrapioid and the hexaploid wheil denoted is $A$. Bl.

A limited number of isozyme markers were also used (Fig. 3. Adenylate kinase IE.C. 2.7.4.3) isozymes have been shown previously to be associated with the long arms oi homologous group- $;$ chromosomes i Benito et al. 1990: Mena et ai. 1992). Endopeptidase (E.C. 3.4.21-24.) isozymes have been assigned to the same chromosome arm of group. 7 chromosomes I Koebner et al. 1988: Mena et at. 1992). The pattern of aconitase (E.C. 4.2.1.3) has bands associated with group-6 chromosomes 1Aco-1: Chenicek and Hart 1987) an that of shikimate dehydrogenase (E.C. 1.1.1.2S) is controlled by group-5 shromosomes (Koebner and Shepherd 1982).

\section{Distribution of markers among $\mathrm{H.93}$ lines}

The distribution of the complete set of markers corresponding to the $\mathrm{MV}^{\mathrm{V}}$ genome among $40 \mathrm{H}-93$ lines is summarized in Table 2. Also included in Table 2 are previously reported data relating to protein $\mathrm{UI}$ and $\mathrm{ACPH}-1$ isozymes (Delibes et al. 1981: 1987) and to ADH-1 isozymes I.Mena et al. 1989). From these data. the following conclusions were drawn. (1) Line H-93-18 carried a segment of the long arm from chromosome $1 \mathrm{M}^{\mathrm{v}}$. but not the complete chromosome. as it lacked another marker from the same arm and a marker from the short arm. Because of the overlapping of fragment(s) corresponding to the $D$ genome of hexaploid wheat with those of the A B genomes. the concomitant disappearence of the D genome marker could not be ascertained. (2) At least a segment of the long arm of chromosome $3 \mathrm{M}^{\mathrm{v}}$ had been exchanged with chromosome $3 \mathrm{D}$ of line $\mathrm{H}-93-3$, but substitution of the whole chromosome is also possible. (3) AI least a segment of the short arm of chromosome $4 \mathrm{M}^{v}$ had been exchanged with chromosome 4D of line H-93-33. 14). Markers of both the long and the short ams of chromosome $5 \mathrm{M}^{*}$ were present in lines $\mathrm{H}-93-8$ and -35 , substituting for chromosome $5 \mathrm{~A}$ in the first case and chromosome $5 \mathrm{D}$ in the second. (5) Markers from both the long and the short arms of chromosome $7 \mathrm{M}^{4}$ were present in lines H-93-1, -8, -10, and -22 substituting for chromosome 7D markers. whereas line -51 had all of the $7 \mathrm{M}^{*}$ 
PSR 162

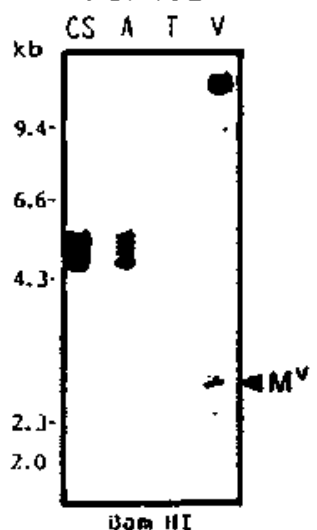

PSR 135

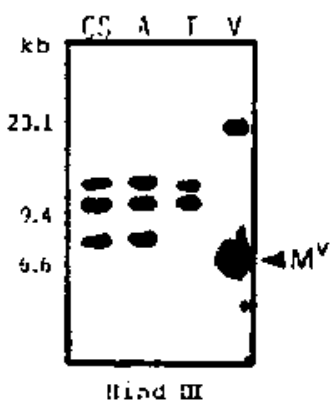

PSR 128

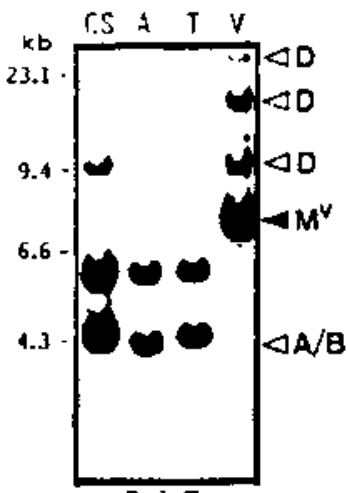

8gl II

PSA129

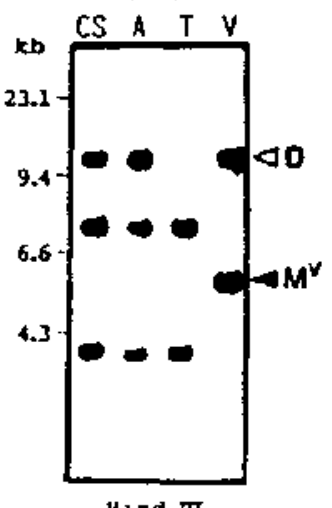

Hind III
PTT1

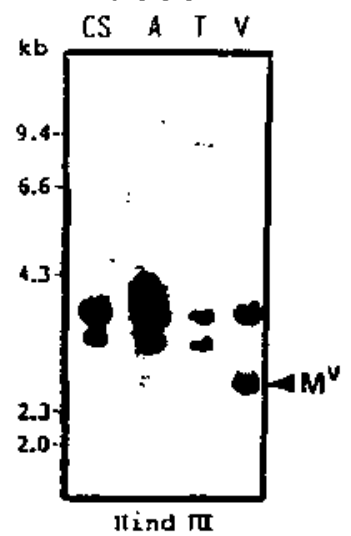

PSR156

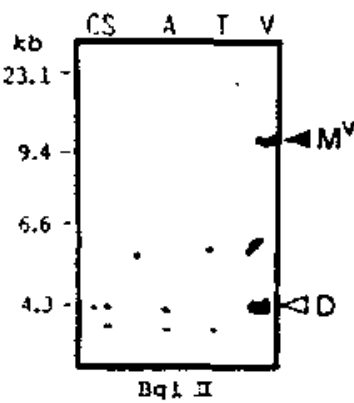

PSRI18

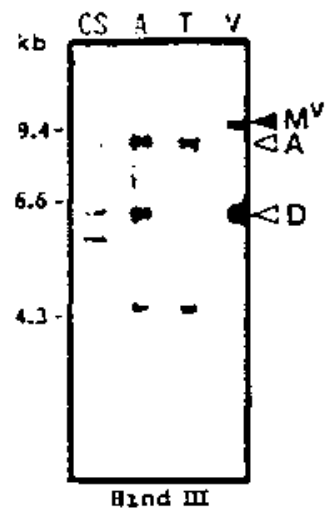

Ssi [P I]

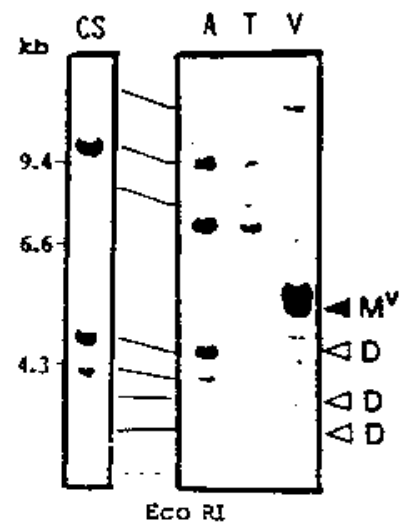

PSR161

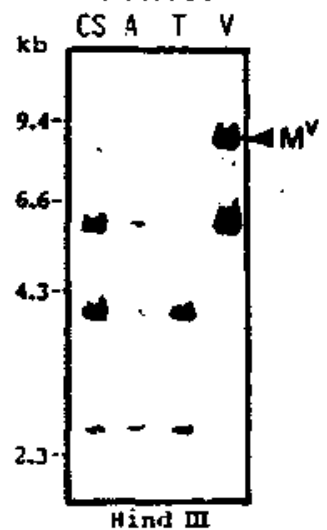

PSR 144

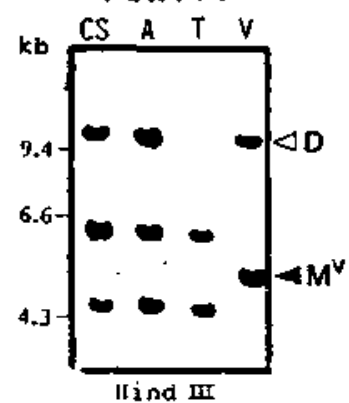

PSR167

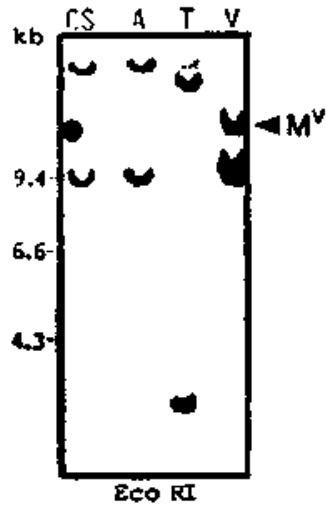

PSR 101

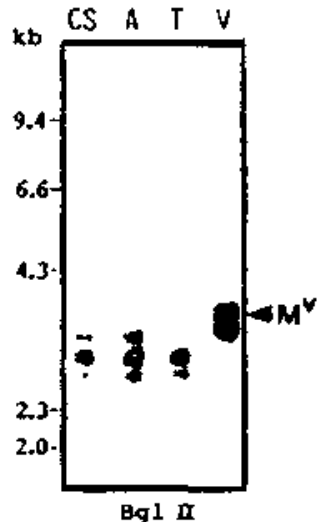

PCT1

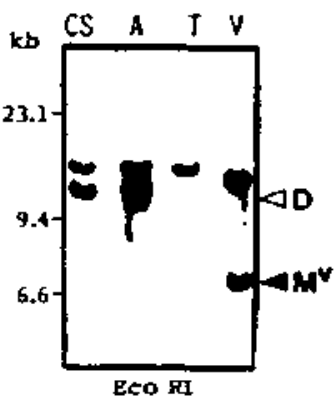

PUP 28

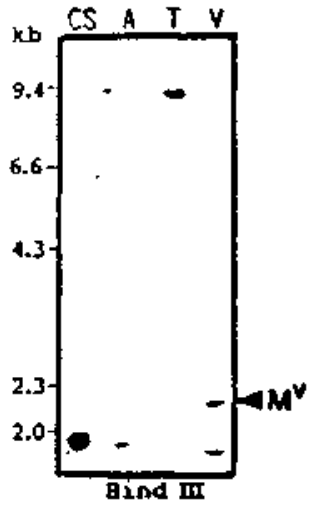

Fig. 2. Southern blot hybridization patterns of DNAs from Triticum aestivum cvs "Chinese Spring" (CS) and "Almatense" $\mathrm{H}-10 \cdot 1 \mathrm{~S}(\mathrm{~A})$. T. turgidum $\mathrm{H} \cdot 1-1$ $(T)$, and te. rentricosa $A \mathrm{P}-1, \mathrm{~V})$ using the indicated cDNA probes. Arrowheads point to diagnostic bands for the indicuted genomes 
Table 2. Distribution of markers from the $\mathrm{M}^{*}$ genome among $\mathrm{H}-93$ lines

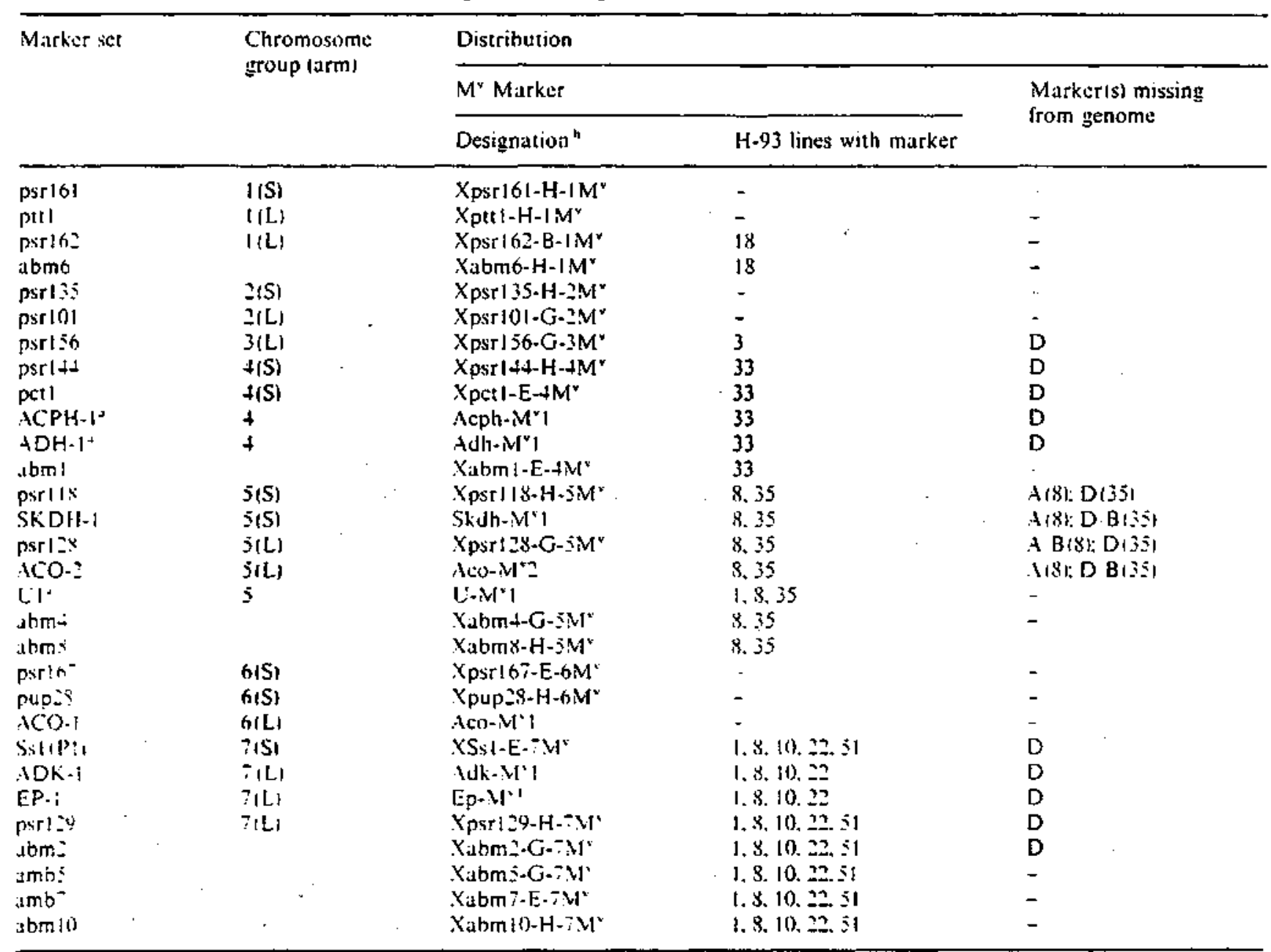

- Data jor protein L'l and ACPH-1 formerly Apin-sl ate from Delibes et al, 11981: 1987): Jata for ADH-1 (formerly ADH

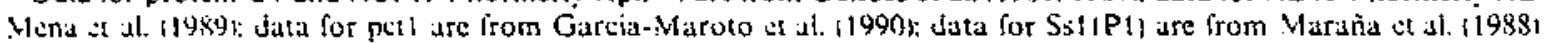

"The following ietters indicate the restriction endonuclease used: B. BamHI: E. EcoR I: G. Bgll: H. Hindfll

markers except (wo. 16) Markers of chromosomes $2 \mathrm{M}^{\mathrm{v}}$ and $6 . \mathrm{M}^{\circ}$ were not detected in the $\mathrm{H} .93$ lines investigated.

\section{Distribution af selected markers}

among wheat the rentricosa addition tines

Selected markers from each of the groups appearing in Table 2 were investigated in the addition lines available that sirried $\mathrm{H}^{\mathrm{v}}$ shromosomes. The $4 \mathrm{M}^{\mathrm{v}}$ addition had been previously identified on the basis of the Adh- $\mathrm{M}^{\mathrm{v}} 1$ and Acph- $\mathrm{VI} I$ (formerly Apt-v) markers (Delibes et al. 1981: Mena et al. 1989). As expected from their grouping in Tadie I. markers Aco- $\mathrm{M}^{2} 1$ appeared in both the $6 \mathrm{M}^{2}$ adoition and the $16 \mathrm{D} / 6 \mathrm{M}^{\mathrm{v}}$ substitution. and Skdh- $\mathrm{V}^{\mathrm{v}} \mathrm{I}$ in the $5 \mathrm{M}^{*}$ addition (Fig. $3 \mathrm{~A}$. B). The putative $7 \mathrm{M}^{*}$ marker Adk-V' 1 appeared in the unidentified addition line $v 172$ (Fig. :C) and so did markers XSs l-E-7M" (Fig. 3D). Ep-

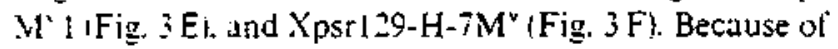
insulfitent bacicrosses the addition lines and the
(6D) $6 \mathrm{M}^{2}$ substitution do not have a uniform ABD background. Additionaliy. the accession of $T$. aethiopicum used as an intermediate to obtain these lines is no longer available. so the observed background variability, which is not only due to introgression from the $A B$ genomes from this species but also to introgression from the $D^{2}$ genome, is difficult to analyze in full. although $\mathrm{M}^{\mathbf{v}}$ bands are readily identified. For example, addition line $6 \mathrm{M}^{\mathrm{x}}$ has the $7 \mathrm{D}^{*}$ allele of endopeptidase instead of that corresponding to chromosome $7 D$. which explains its high resistance to eyespot disease 1, Mena et al. 1992) and indicates that this resistance is not due to the added chromosome is previously thought (Dosba and Doussinault 1981). The same explanation would be valid in the case of the Aco-1 pattern of addition line $6 \mathrm{M}^{*}$. Another example of background variability is represented by the sucrose synthase Ssl (P1) partern of the $+\mathrm{M}^{*}$ addition. which shows an additional fragment asso present in .fe. 'entricosa. This fragment could represent either a second 
A AcO

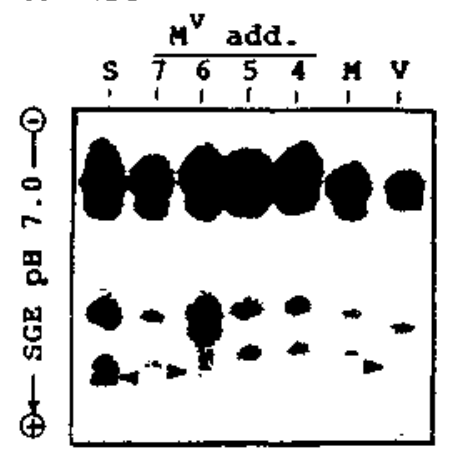

C Adk

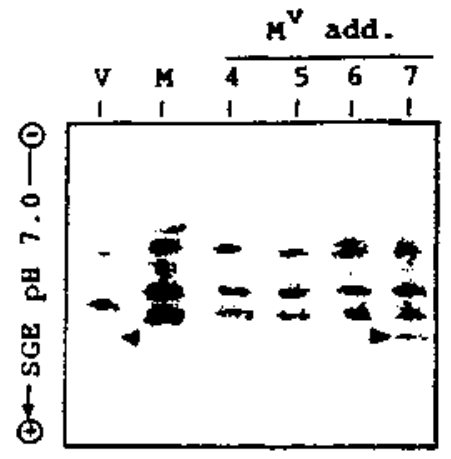

E Ep

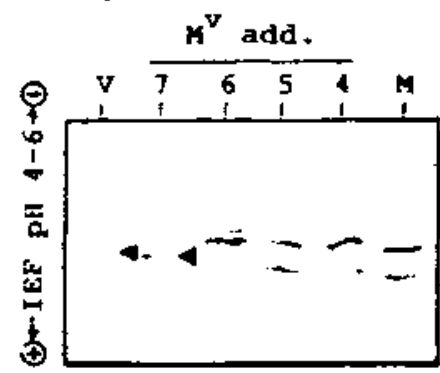

B Skdh

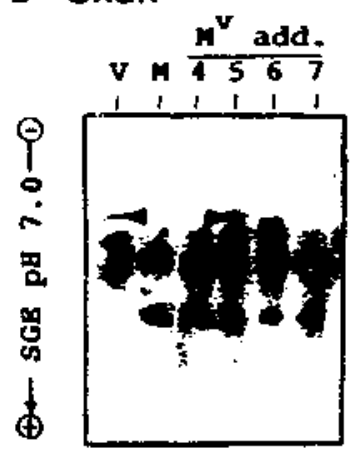

D Ss1

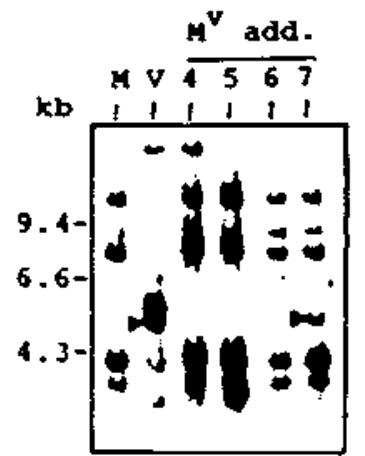

F psr129

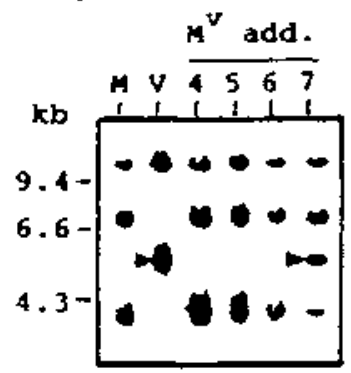

Fig. 3A-F. Distribution of selected markers imong wheattegitons ientricosa addition lines. The following stocks were analyzed: Trisicum uestivum $\mathrm{cv}$ "Moisson" (.M) Ae. ventricosa no. 11 (l) addition lines $4 M^{*}\{v \mid 77), 5 M^{*}(v 208), 6 M^{*}(v 260)$. and $7 \mathrm{M}^{*}\left(\mathrm{vi}_{72}\right)$, and substitution line $\left.\left.16 \mathrm{D}\right) 6 \mathrm{M}^{*}: S\right)$. The identities of the addition lines in parentheses correspond to Dosba (1985). Markers analyzed were: A aconitase isozyme furrowhead indicates $\left.f(0)-\mathrm{M}^{*} 1\right):$ B shikimate dehydrogenase isozymes (arrowhead indicates $\$ k d h \cdot \mathrm{M}^{\vee} 1 \mathrm{k}: \mathrm{C}$ adenilate kinase isozymes (ar-

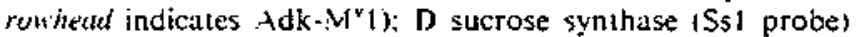
RFLP patterns (EcoR:: arrowhead indicates XSsI-E-7:M| ${ }^{*}$ ): E endopeptidase isozymes tarrowhead indicalies $\left.E_{p}-M^{2} 1\right)$ : F RFLP pattern obtained with eDNA probe psrl 39 (HindIII: arrowinead indicates Xpsr129-H-7M

Ss1-type locus or background variability due to T. uethiopicum.

Clrogentic study of selected $\mathrm{H}-93$ lines

The existence of chromosome substitutions in lines H-93-1. $-8 .-10 .-33$. and -51 has been investigated previ-

A

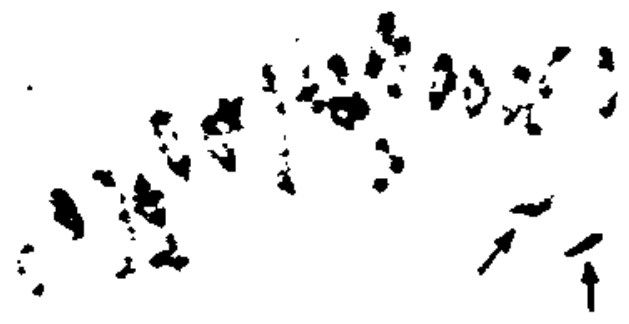

B
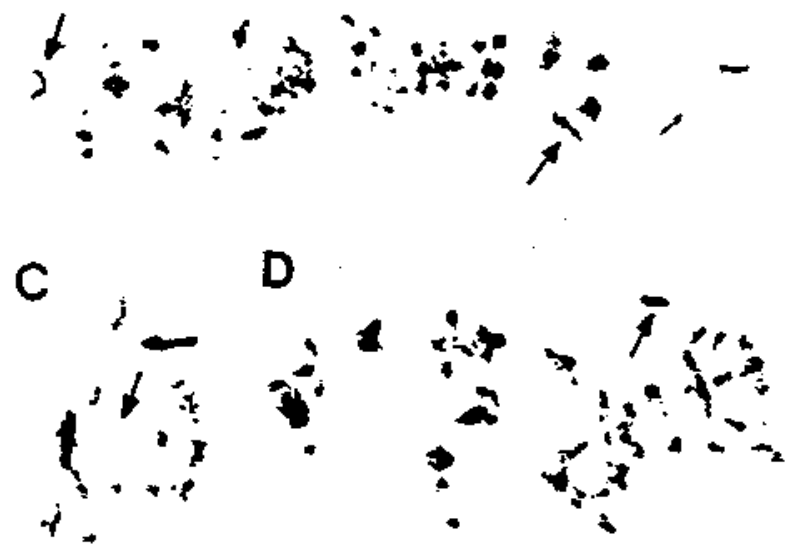

Fig. +A-D. Weiocic analysis of Giemsa C-banding of the lollowing hybrids: A $T$ asessirum cv "Almatense" $\mathrm{H}-10-15 \times \mathrm{H}-93+1$ : B H-93-i x H-93-X; C $T$. asestim ov "Chinese Spring". ditelosomic 5DL $\times$ H.4:-S: D T. uestin'un cv "Chinese Spring". direlosumic $5 \mathrm{DL} \times \mathrm{H}-4: 55$. A. B Arows point to unpiared chromosomes: C, D arrows point to SD telosome

ously in routine analysis of the number of univalents at meiosis in hybrids with $T$. cestivum cv "Almatense" H-10-15 (Delibes et al. 1977 a. b. 1987; Mena et al. 1989, 1992). Hybrids between lines H-93-1, -8. -35 and T. aestivum showed two. four. and two univalents. respectively.

In order to conlirm presence the $\mathrm{M}^{*}$ chromosomes in these lines a further cytogentic analysis using the Giemsa C-banding technique was carried out. As expected in $\mathrm{H}-10-15 \times \mathrm{H}-93-1$ hybrids. two univalents were found at metaphase 1 . one with dispersed and scattered heterochromatin characteristic of the $\mathrm{M}^{*}$ genome and the other without any C-band. like chromosomes of the D genome (Fig..++1 ). This result is consistent with the existence of the $7 \mathrm{D}, \mathrm{TM} \mathrm{M}^{4}$ ) substitution detected by molecular markers.

Two univalents were also observed in the H-93-1 $x$ H-93-8 hybrid one highly $C$-banded and the other without $C$-heterochromatin. However, in this case the heavy banded chromosome had a different $C$.banding pattern than that in the previous hybrid IFig. + B). The existence of two chromosome substiturions. probably $7 \mathrm{D}\left(7 \mathrm{M}^{\mathrm{v}}\right)$ 
Table 3. Substitution of genetic material from the $\mathrm{M}^{\mathrm{v}}$ genome in H-93 lines

\begin{tabular}{|c|c|c|}
\hline Line $\mathrm{H}-93$ & Chromosome & $\begin{array}{l}\text { Chromosomal } \\
\text { segment }\end{array}$ \\
\hline $\begin{array}{l}1 \\
3\end{array}$ & $7 \mathrm{D} / 7 \mathrm{M}^{*}$ & $\begin{array}{l}\text { 5D?/SM" } \\
3 \mathrm{D} / 3 \mathrm{M}^{v}\end{array}$ \\
\hline 8 & $5 A / 5 M^{*} ; 7 D / 7 M^{*}$ & 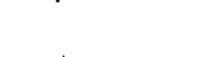 \\
\hline $\begin{array}{l}10,22 \\
18\end{array}$ & $\mathrm{D} / \mathrm{M}$ & $1 \mathrm{D} ? / 1 \mathrm{M}^{*}$ \\
\hline $\begin{array}{l}33 \\
35\end{array}$ & $\begin{array}{l}4 \mathrm{D} / 4 \mathrm{M}^{2} \\
5 \mathrm{D} / 5 \mathrm{M}^{\mathrm{v}}\end{array}$ & \\
\hline 51 & (18.⿲丿丨 & $7 \mathrm{D} / 7 \mathrm{M}^{*} / 7 \mathrm{D}^{\circ b}$ \\
\hline
\end{tabular}

and $5 \mathrm{~A}\left(5 \mathrm{M}^{7}\right)$ in $\mathrm{H}-93-8$, was confirmed by the presence of lour univalents in its hybrid with "Chinese Spring" SDL, whete telosome 5DL was always paired (Fig. 4C), and excluded the possibility of a $5 \mathrm{D}\left(5 \mathrm{M}^{\mathrm{v}}\right)$ substitution. Therefore, lines $\mathrm{H}-93-1$ and $\mathrm{H}-93-8$ have a substitution in common, $7 \mathrm{D}\left(7 \mathrm{M}^{2}\right)$, and differ in a second one, $5 \mathrm{~A}\left(5 \mathrm{M}^{2}\right)$, that is present only in H-93-8 (see Table 2). The results shown in Table 2 indicate that line H-93-35 has a $5 \mathrm{D}\left(5 \mathrm{M}^{v}\right)$ substitution. This was confirmed in hybrid Dt5DL $\times$ H-93-35, where telosome SDL was never paired (Fig. 4D).

These results seem to confirm predictions based on the distribution of molecular markers.

\section{Discussion}

Joint consideration of the distribution of chromosomal markers and the cytological data allowed us to conclude that the breeding scheme had resulted in the incorporation of genetic material from the $\mathrm{M}^{\mathrm{v}}$ genome of Ae, ventricosa into the $\mathrm{H}-93$ lines both by the introgression of chromosomal segments and by chromosome substitution. Thus, lines $H-93-1,-18$, and -51 , and possibiy line $\mathrm{H}-93-3$, had integrated segments from $\mathbf{M}^{\mathbf{2}}$ chromosomes, while lines $\mathrm{H}-93-1,-8,-10,-22,33$, and -35 had substitutions. Table 3 summarizes our conclusions concerning these lines. A more detailed account of H-93-51 has been recently pubiished (Mena et al. 1992). The present data obtained with probe psr144 further supports the previous characterization of line $\mathrm{H}-93-33$ as a $(4 \mathrm{D}) 4 \mathrm{M}^{*}$ substitution (Mena et al. 1989).

The distribution of markers among the addition lines confirms the identification of those corresponding to cbromosomes $5 \mathrm{M}^{\mathrm{v}}$ and $6 \mathrm{M}^{\mathrm{v}}$ and allows the identification for the first time of that carrying chromosome $7 \mathrm{M}^{2}$.

Acknowledgements. We gratefully acknowledge the gift of the cDNA probe by Dr. M. Gale and the technical assistance from
D. Lamoneda and I. Garcia. This work was supported by Grants PBT 87-0012 and AGR89-0193 from the Comision Interministerial de Ciencia y Tecnologia, Spain.

\section{References}

Benito C, Gallego FJ, Frade JM, Zaragoza C, Figueiras AM (1990) Chromosomal location of adenylate kinase isozymes in Triticeae species. Theor Appl Genet 79:157-160

Chenicek KJ, Hart GE (1987) Identification and chromosomal locations of aconitase gene loci in Triticeae species. Theor Appi Genet 74:261-268

Delibes A, Garcia-Olmedo F (1973) Biochemical evidence of gene transfer from the $\mathrm{M}^{v}$ genome of Aegilops ventricosa to hexaploid wheat. In: Sears ER, Sears LMS (eds) Proc 4th Int Wheat Genet Symp. Missouri Agric Exp Str. University of Missouri. Columbia MO, pp 161-166

Delibes A, Dosba F, Doussinauit G, Garcia-Olmedo F, SanchezMonge R (1977a) Resistance to eyespot (Cercasporella herpotrichoides) and distribution of biochemical markers in hexaploid lines derived from a double cross (Triticum turgidum $\times$ Aegilops ventricosa) $\times T$, aestivum. In: SanchezMonge E. Garcia-Olmedo $F$ (eds) Interspecific hybridization in plant breeding. Proc 8th Congr EUCARPIA. Polytechnic University. Madrid. pp 91-97

Delibes A, Sanchez-Monge R, Garcia-Olmedo F (1977 b) Biochemical and cytological studies of genetic transfer from the $M^{*}$ genome of Aegilops ventricosa into bexaploid wheat In: Sanchez-Monge E, Garcia-Olmedo F (eds) Interspecific hybridization in plant breeding. Proc 8 (b Congr EUCARPIA. Polytechnic University, Madrid, pp 81-89

Delibes A, Otero C, Garcia-Olmedo F (1981) Biochemical markers associated with two $M^{*}$ chromosomes from Aegilops ventricosa in wheat-Aegilops addition lines. Theor Appl Genet 60:5-10

Delibes A. Lopez-Brāna I. Mena M, Garcia-Olmedo F (1987) Genetic transfer of resistance to powdery mildew and of an associated biochemical marker from degilops ventricosa to hexaploid wheat. Theor Appl Genet 73:605-608

Dosba F (1974) Comparison of mean mejotic pairing of two types of hybrids ( $T$. aestivum ssp. vulgare $\times$ Ae. ventricosa) with and without chromosome SB. Cereal Res Commun 2:141-146

Dosba F (1985) Méthodologie du transfert des génes d'Aegilops ventricosa à Triticum aestivum; analyse citogénétique d'bybrides interspécifiques et étude de lignnes d'addition bièAegilops. PhD thesis, Universite de Paris-Sud, Paris

Dosba F, Cauderon Y (1972) A new interspecific bybrid Triticum aestivum ssp. whlgare $\times$ Aegilops ventricosa. Wheat Inf Serv 35:22-24

Dosba F, Doussinauit $G$ (1978) Création de lignoées de blé preséntant les caractéristiques agronomiques favorables d'Aegilops ventricosa. Ann Amelior Plant 28:27-44

Dosba F, Doussinault $G$ (1981) Les lignnes d'addition blé Aegilops ventricosa. I. Etude du comportement vis à vis du piètin-verse des differentes lignnée obtenues. Agronomie 1: $503-511^{\circ}$

Dosba F, Rivoal R (1981) Les lisunnées d'addition blé - Aegilops ventricosa Tausch. II. - Etude de leur comportement et de celui de leurs progeniteurs vis-à-vis d' Heterodera avenae Woll. Agronomie 1:559-564

Dosba F. Tanguy AM, Douaire G (1980) Study of the characteristics linked to an $\mathrm{M}^{*}$ chromosome of Aegilops ventricosa in an addition line wheat-Aegilops. Cereal Res Commun $8: 501-507$ 
Dosba F, Doussinault G, Jahier J, Trottet M (1982) Utilisation d'especes sauvages dans l'amélioration de l'état sanitaire du blé tendre: Triticum aestivum. In: La sélection des plantes. (Les colloques de l'INRA no. 11). INRA Publ, Bordeaux, France. pp 75-85

Doussinault G. Deibes A, Sanchez-Monge R, Garcia-Olmedo $F$ (1983) Transfer of a dominant gene for resistance to eye. spot disease from a wild grass to hexaploid wheat. Nature 303:698-700

Feinberg AP, Vogelstein B (1983) Technique for radiolabeling DNA restriction endonuclease fragments to high specific activity. Anal Biochem 132:6-13

Garcia-Maroto F, Maraña C, Mena M, Garcia-Olmedo F, Carbonero P (1990) Cloning of cDNA and chromosomal location of genes encoding the three types of subunits of the wheat tetrameric inhibitor of insect $x$-amylase. Plant $\mathrm{Mol}$ Biol 14:845-853

Giraldez R, Cermeño MC. Orellana J (1979) Comparison of $C$-banding pattern in the chromosome of inbred lines and open-pollinated varieties of rye. Z Pflanzenzuecht 83:40-48

Jones ET (1938) Infestation of grasses of the genus Aegilops by Hessian fly. I Econ Entomol 31:121-132

Koebner RMD, Shepherd KW (1982) Shikimate dehydrogenase - a biochemical marker for group -5 chromosomes in the Triticinae. Genet Res 4t:209-21 3

Koebner RMD. Milier TE, Snape JW, Law CN (1988) Wheat endopeptidase: genetic control, polymorphism, intrachromosomal gene location, and alien variation. Genome $30: 186-192$

Landry BS, Michelmore RW (1985) Selection of probes for restriction fragment length analysis from plant genomic clones. Plant Mol Biol Rep 3: 174-179
Maraña C, García-Olmedo F, Carbonero P (1988) Linked sucrose synthase genes in group-7 chromosomes in hexaploid wheat (Triticum aestivum L.). Gene 63:253-260

Mena M (1990) Caracterización de lineas de trigo (Triticum aestivum L.) portadoras de genes de Aegilops ventricosa Tausch. que conlieren resistencia a hongos y nematodos. PhD thesis, Universidad Compluteose, Madrid

Mena M, Orellana J, Lopez-Braña I, García-Olmedo F, Delibes A (1989) Biochemical and cytological characterization of wheat/Aegilops ventricosa addition and transier lines car* rying chromosome $4 \mathrm{M}^{2}$. Theor Appl Genet 77:184-188

Mena M, Doussinault $G$, Lopez-Braña I, Aguaded S, GarciaOlmedo F, Delibes A (1992) Eyespor resistance gene Pch-1 in $\mathrm{H}-93$ wheat lines. Evidence of linkage to markers of cbromosome group-7 and resolution from the endopeptidase locus Ep-D/b. Theor Appl Genet 83:1044-1047

Murray MG. Thompson WF (1980) Rapid isolation of highmolecular-weight plant DNA. Nucleic Acid Res 8:43214325

Rogers SO, Bendich AJ (1988) Extraction of DNA from plant tissues. Plant Mol Biol Manual A6: 1-10

Sambrook J, Fritsch EF, Maniatis T (1989) Molecular cloning: a laboratory manual. Cold Spring Harbor Laboratory Press. Cold Spring Harbor, N.Y.

Sharp PJ, Chao S, Desai S, Gale MD (1989) The isolation, characterization and application in the Triticeae of a set of wheat RFLP probes identifying each homoeologous chromosome arm. Theor Appl Genet 78:342-348

Sprague R (1936) Relatjve susceptibility of certain species of gramineae to Cercosporella herpotrichoides. J Agtic Res $53: 659-670$ 